\title{
Resenha
}

A função paterna na instituição - do individual ao coletivo

Cristina Hoyer

Rio de Janeiro: Garamond Universitária, 2010, 168p.

\section{UM ESPAÇO VIVO E CHEIO DE PSICANÁLISE}

\section{Leda Mariza Fischer Bernardino}

$\mathbb{4}$ de disponibilidade de escuta. Cristina Hoyer se aventurou fora do setting psicanalítico e aplicou o dispositivo da escuta analítica ao campo social, no caso, uma escola. Não recuou diante do desafio e pôs o desejo em ação: teve a coragem de criar uma instituição, e mais coragem ainda ao imprimir-lhe uma direção psicanaliticamente orientada. Depois de dezesseis anos (que hoje já somam dezenove) de experiência institucional, além de muitos anos de prática clínica psicanalítica, outro ato de coragem: voltou ela mesma aos bancos da escola para pôr-se a estudar nada menos do que... função paterna na instituição!

A autora se lançou nessa empreitada com a pertinácia que lhe é própria: percorreu os textos freudianos e lacanianos com afinco, retirando dos conceitos sua explicação mais genuína. Este livro apresenta ao leitor o resultado de todas essas iniciativas, que nos presenteiam com uma sistematização ímpar de conceitos freudianos e lacanianos em torno da difícil questão do Pai. Não bastasse isso, a autora ainda permeia seu texto com referências literárias, ligando

\footnotetext{
- Psicanalista. Membro-fundador da Associação Psicanalítica de Curitiba. Analista-membro da Association Lacanienne Internationale. Doutora em Psicologia Escolar e do Desenvolvimento Humano pela Universidade de São Paulo (USP). Professora titular pela Pontifícia Universidade Católica do Paraná (PUC-PR). Autora do livro As psicoses não decididas da infância: um estudo psicanalíitico (Casa do Psicólogo, 2004).
} 
o Pai à Palavra de um modo muito sensível e criativo.

Enfim, Cristina responde com seu trabalho à crucial pergunta "o que é um Pai?” e mostra como é possível dispor desse operador em um trabalho social e institucional.

No que se refere ao trabalho teórico, o livro de Hoyer é extremamente didático e instigante; encontramos aí a teoria freudiana do Complexo de Édipo, do Complexo de Castração, o resgate dos textos ditos culturais de Freud, com que a autora vai aos poucos preparando o terreno para mostrar a operatividade desses conceitos na instituição. Por exemplo, explica que "O recalque é a construção que permitirá ao sujeito participar do sistema social, comunitário e civilizatório, no qual deve exercer determinadas funções, de preferência produtivas" (p. 27).

Ao introduzir as ideias lacanianas, a autora faz a ponte: "Coube a Jacques Lacan, ao longo de sua obra, realizar o nexo essencial entre o mito freudiano e a dimensão antropocultural oferecida por Lévy-Strauss, a fim de possibilitar uma melhor compreensão da proibição do incesto e sua repercussão na função paterna" (p. 37).

Cristina Hoyer reconstrói em seu texto o arcabouço teórico lacaniano que possibilitou o conceito de Nomedo-Pai: linguagem e sujeito do inconsciente - Outro, significante, outro, objeto, esquema L; os três registros; a metáfora paterna. Ao trabalhar, o 
conceito de coletivo institucional, a autora passeia pelos conceitos, formulados por Freud, de massa organizada, identificação, traço unário, Ideal do $\mathrm{Eu}$, eu ideal, narcisismo, para finalizar abordando os fenômenos imaginários que permeiam os grupos.

O capítulo 4 é especialmente notável, ao tratar da insuficiência do Nome-do-Pai e chegar à análise da família, a primeira instituição, matriz psíquica, que preside a construção da realidade e a relação com a cultura.

Como preliminar à experiência de campo, no capítulo $5 \mathrm{a}$ autora esmiúça a questão dos quatro discursos propostos por Lacan, para formular uma de suas perguntas de pesquisa: se na instituição predomina - por questões de estrutura - o discurso do mestre, "como promover numa instituição a torção necessária para que o discurso psicanalítico possa operar, a fim de permitir o surgimento de sujeitos?” (p. 117). E quem deve ocupar esse lugar de sujeito? Aí percebemos a dimensão do desafio que a autora enfrentou: "'beneficiários', 'doentes', loucos', 'marginais', 'pobres', entre outras denominações”. A dimensão subversiva da psicanálise aparece em toda a sua extensão.

Hoyer traz o exemplo de três outras instituições balizadas pela psicanálise lacaniana: Bonneuil, o Lugar de Vida e Le Courtil, que, apesar de suas diferenças de nacionalidade e estilo, têm ainda outra particularidade em comum: o trabalho com crianças psicóticas.

Chegamos então ao capítulo 6, em que a autora apresenta seu Espaço Vivo, hoje compartilhado por crianças e adolescentes da comunidade que chegam a partir de um sofrimento próprio, de seus familiares ou das instituições sociais. Ao contar a história do surgimento desse espaço, vemos na prática como é não atender à demanda de um saber pronto do pretenso especialista e encontrar um psicanalista que se propõe a transformar demanda em aposta, em busca da construção de um saber de cada sujeito que por ali circule. É quando somos apresentados à maneira como ali a psicanálise sustenta o trabalho institucional e a uma particular forma de alteridade, sustentada em uma ética: uma fundadora que se transforma em trabalhadora decidida.

Essa é uma definição que cabe a Cristina Hoyer, uma psicanalista que é uma trabalhadora decidida e que ao se aventurar pelos meandros do precário campo social de nosso país e pelas sinuosas curvas da pesquisa universitária nos brinda com um exemplo de vida e de prática clínica.

628 Estilos clin., São Paulo, v. 18, n. 3, set./dez. 2013, 626-629. 


\section{Resenha}

Ao finalizar a leitura das considerações finais, a sensação que tive foi de gratidão: obrigada, querida Cristina, por ter tornado tão cristalina e sistematizada essa noção de função paterna e obrigada também por nos mostrar que o psicanalista pode ser um trabalhador social ao levar seu dispositivo de escuta e de sustentação de desejo para além das quatro paredes!

ledber@terra.com.br Avenida Batel, 1920/210 80420-090 - Curitiba - PR - Brasil. 